\title{
Rethinking Teacher Incentives Paid By Parents/ Guardians Of Learners In Zimbabwe: A Labour Relations And Sociological Perspective
}

\author{
Angela Maposa
}

\begin{abstract}
A large portion of Zimbabwean parents/ guardians saw great relief when teacher incentives were introduced. This followed a spate of industrial actions such as strikes, demonstrations, stay-always. The introduction of teacher incentives meant that students could go back to school and learn. This paper argues that this move did not solve the problem of low teacher remuneration. It attended to the symptoms, but left the cause(s) getting more and more malignant. It examines the twin-evils that have been born by teacher incentives. The inequalities that existed before Zimbabwe became politically independent, are being perpetuated in the sense that the poor families are segregated. They have no access to quality-education simply because they cannot afford to raise the teacher incentives. Worse still, unionism especially for civil servants has been crippled.

I found that these community based incentives are a widespread phenomenon, with adverse implications to the whole education system. The employer, (i.e the public service commission) has abdicated its responsibility of motivating its employees (teachers) to the consumers (i.e the parents and guardians). Demotivation abounds and teacher subsidise their income through "Extra lessons" a phenomenon that cannot be controlled.
\end{abstract}

\section{Background To The Study}

The post colonial education system was geared towards eliminating the discriminatory practices and increase access to education. In line with one of the Millennium Development Goals, it aimed at Education for all. this resulted in unprecedented expansion of the enrolment figures as schools mushroomed all over the country. According the Nziramasanga Commission (1999) enrolment in the primary schools rose by $176,8 \%$ and $950,5 \%$ in the secondary schools. Teacher training colleges stopped up their programmes in order to meet the growing demands for trained teachers. The Zimbabwe Intergrated Teacher Education College (ZINTEC)was a major resolution because it enables trainees to spend more time out in the schools, on teaching practice.

In 1987, the Education Act abolished the Unified Teaching Service (UTS). The transfer of teachers from the UTS to the Public Service Commission increased the financial obligations of Government. Expansion of the school system forced the Government to adopt the idea cost recovery. Education was no longer "free" and fees had to be paid. The economic downturn of the country worsened the plight of the teachers. Thousands left the country for greener pastures in the neighbouring countries and overseas. The teachers who remained in the system did not execute their duties effectively because they were demoralised. The Statutory Instruments 87 of 1992 made provisions for school Development Committees and School Development Associations. So parents had to intervene, for the sake of their children's education. Incentives depend on how affluent the parents/ guardians of the learners are. The poor communities in the high density suburbs and those in peri-urban, rural and remote areas also lost their teachers to school that paid better. The concept of equity thus suffered.

In real time with violation of the concepts of equity and equality, Watkins (2000:225) says, "Many developing countries have been developing authority away from the central government to local service providers in an effort to improve efficiency and equity of service provision................. where decentralisation weakens, the distribute role of the state, it can widen already extreme inequalities in education......."

The payment of incentives makes parents more powerful and teachers no longer see the need to subscribe to Zimbabwe Teachers Association (ZIMTA) nor to attend its meetings. Loyalty and respect are directed towards the parents who have become "employers" as it were.

\section{Major Research Problem}

The payment of teacher- incentives by parents/ guardians has adversely affected Trade Unionism and made quality education remain inaccessible to the low socio- economic strata of society in Zimbabwe. 
This paper sets out to:

\section{Objectives Of The Study}

* Explore the post- colonial Education Policies.

- Describe the history, role and function of Teacher Organisations (ZIMTA, Z)

* Determine the ways in which school based incentives render Teacher Organisations "toothless dogs"

* Explain why membership to and attendance to meetings of Teacher organisations is low.

* Analyse the relationship between teacher incentives and pass- rate in public examinations.

- Suggest possible ways of repairing the status of the teaching profession

- Make recommendations for promoting and assuring quality education in all types of schools.

\section{Significance Of The Study}

The study should consolidate the knowledge base concerning implications of school based incentives, to the entire education system. Teachers ought to realise that they too contribute to the continual poor salaries because they accept school based incentives. Findings of the paper are meant to improve the perceptions and practices of policy markers and planners. The legislation which is a handicap to civil servants has to be fully understood by the teachers. The Labour- Relations dimension makes this particular study different from these that have just blamed the economy for poor remuneration of teachers.

ASSUMPTIOS

It was assumed that the School Development Association (SDA) and School Development Committee (SDC) and teacher Trade Union official would corporate. Another assumption was that some teachers were indeed motivated by school based incentives and would proudly and freely reveal how much they received, in addition to the Salary Services Bureau payments. I also assumed that the teachers who were not receiving incentives would also reveal how demotivated they were.

\section{Delimitation}

The study was confined to selected schools in Harare urban, peri-urban, farms and re-settlements in the Karoi District. From each school, I manage to interview a member of the parent/ teachers association (SDA/ SDC), teachers. I included some parents per school type and I had the priviledge to interview Trade Union Leaders from Zimbabwe Teachers Association (ZIMTA) and Progressive Teachers Union of Zimbabwe (P.T.U.Z)

\section{Limitations}

This topic was, in several instances misconstrued and perceived as anti- Government. I had to tactfully alter my approach as I proceeded with interviews. In most cases I had to use the first language of the participant (i.e. SHONA) when I interviewed members of the community (i.e. parents). This was particularly the case on the farms and in the high density residential areas. I circumvented the language barrier because even if my first language is Ndebele, I am equally fluent in Shona. Translation of the response was time consuming.

Distance between schools posed a real problem and I used a month from month vocation leave days and all my occasional leave days in the year 2012 to reach all the targeted schools. I took advantage of the Zimbabwe Open University weekend tutorials (Faculty of Education) whose part time tutors and the majority students are trained teachers. This strategy enabled me to maintain the scope of the study while minimising cost because questionnaire were completed at the tutorial venue and handed over to the Regional Programme Coordinators.

Furthermore, I took advantage of the National Association of Secondary Heads (NASH) and National Association OF Primary School Heads (NAPH) Annual Conferences and managed to get questionnaires completed

\section{Compensation}

\section{Literature Review}

Moorhead and Griffin (1995) say the reward system is made up of organisational aspects that involve the allocation of compensation and benefits to employees in exchange for their work. They go on to explain that "tangible compensation consist of rewards that have a definite value, such as pay....." moreover rewards also carry symbolic value in that they convey to people how much they are valued by their employer (Douglas B Gehrman 1984) quoted in Moorhead and Griffin (1995)

The most important form of reward is money. Money is important because of the goods and services it can buy. Furthermore, it can also symbolise an employees worth. This study brings in the connotations of the foregoing observations to the participants during collection of data. According to Milkovich and Newman (1996) compensation is an entitlement: something that the employer Public Service Commission in the study) is obliged to pay in return for, services rendered, no matter how poorly. Armstrong has to do with rewarding employees fairly, equitably and consistently in accordance with their value in the organisation (Ministry of 
Education in this study). This is where the crux of the research problem is: Are the teachers content with the value being placed on their profession and service delivery?

Adams and Jacobs (1976) quoted in Magaramombe et.al (2003), in their research on Effects of Wage Inequalities on Work Quality suggest that people at work compare themselves with others doing similar work in similar circumstances and judge whether they are being fairly paid. A teacher at Dema Primary School (Seke District ) compares himself to a teacher at Vainona Primary School and feels the she/ he is not being treated equitably. This paper included this concern in interacting with participants.

\section{Motivation}

Taken simply, motivation is the set of forces that lead people to behave in particular ways.

Educational institutions get high pass rates and good reputation through teachers. No matter how perfect their infrastructure; their teacher pupil ratios; availability of textbooks; tools of control etc, schools cannot achieve much without willing and motivated workforce. Cole (1986:7) noted that people are the greatest/ most valuable asset available to an organisation. It is necessary to note that the human beings (teachers in this study) are the only asset that can actively work against the organisation' goals. It is most likely that low pass rates in public examinations are linked to lack of motivation. However motivation remains important in organisation because in conjunction with ability and environment it determines performance. The conceptual framework that informs this study can be traced from as far back as Taylor's scientific management $\left(19^{\text {th }}\right.$ Century), on to the Human Relations Theories by Maslow's; Clayton (1972) who cam up with the existence, Relatedness and Growth (ERG) theory of motivation. This is according to Statt (1994:88). Then there was Herzberg's Motivation hygiene Theory, which cited "salary" among the factors that lead to extreme dissatisfaction (Vroom and Deci, 1970)

\section{NEED THEORIES OF MOTIVATION}

A need is anything an individual requires or wants. In their motivational Framework, Jack and Elizabeth (1989) they show that a need deficiency usually triggers a search for ways to satisfy it. This study is interested in discovering the methods used by disgruntled teachers to meet their need. Frederick W Taylor, the chief proponent of scientific management argued that employees work so as to earn as much money as possible. Among the best known need theories are the ERG theory and Maslow's hierarchy of needs. In the needs hierarchy, categories of deficiency needs are as shown (below or next page whichever the case maybe)

The case study conducted in Kenya (Glewwe, Nauman and Kremer 2008: 54 revealed that incentives actual exceed what can be achieved through trade union bargaining. But the same study found out that absenteeism by teachers was rampant, thus proving Mc Gregor's theory " $\mathrm{X}$ " right. Perhaps the major determinant lies with the leadership skills of the school head.

\section{Maslow's Hierarchy of needs}

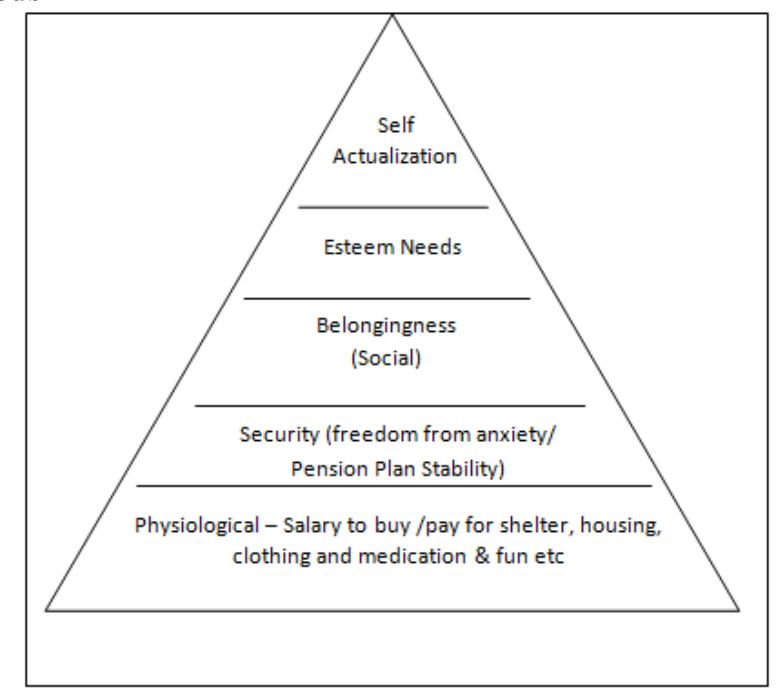

Source: Maslow A: (1954) New York, Harper \& Row

I wanted to find out where the teachers fit it and what survival strategies they a have adopted to meet their needs. Where do the teachers' incentives place them on the hierarchy? There is a very close relationship between the ERG Thorny and Maslow's 


\section{Process Based Perspectives On Motivation}

These focus on how motivated behavior occurs in an effort to satisfy needs. The equity theory is based on the fact that people under the same empower want to be treated fairly (Adam 1987). People are said to start by evaluating how they are being treated by the employer. Next, they evaluate how their counterparts are being treated. After evaluating the treatment of self and their counterparts are being treated. After evaluating the treatment of self and "other" the individual might be comparing themselves: some are not getting and incentives as all / those that are getting them in wanted them to know how much more or less the next school was paying. Teachers tended to reduce their efforts because they felt that they were under - rewarded.

Participative management and empowerment represent important process-based perspectives on employee motivation. Participation is the process of giving employee a voice in making decisions about their own work. This is where teacher organizations like ZIMTA and PTV come in, to represent teachers. The findings were compares to such perspectives.

\section{The Employer of Teachers}

In Zimbabwe the employer of teachers is the Public Service Commission. In addition to receiving employers into service, the employer is also obliged to pay remuneration agreed upon. Remuneration may include allowances for housing and transport. Section 2 of the Labour Relations Act, Chapter 28:01 defines a Trade Union as "Any association or organisation formed to represent or advance the interest of any employees or a class thereof, in respect of their employment."

It turned out later that even though the Labour Act recognizes the fundamental right of employees, to join workers' committee or a trade union the Ministry, the Public Service Act (1996) Chapter 16:04, Section 20, subsection 11 and (2) reduces the role of civil service worker organisations to mere consultations and not collective bargaining. The majority of the professional participants in the sample were asked if they understood the difference between consultation and collective bargaining.

In 2009, the Permanent Secretary for the education Sport and Culture issued a circular to school Development Committees, directing them to come with incentives for their teachers. He wrote: "Incentives for teachers": That SDCs are hereby encouraged to com up with measures to attract and retain qualified teachers in schools. Such measures could include incentives either in cash or in kind. However, no teacher should demand these from parents. This follows drastic disturbances which saw Term 1 beginning on 02 March instead of the scheduled 13 January. Salary disputes with government resulted in teachers spending the greater part of 2008 at home instead of their work stations.

The fact that the Public Service Wage Bill is part of the expenditure component of the national budget, poses a challenge to collective bargaining in the public service. The fiscal determination of what constitutes the wage bill as a percentage of the gross domestic product (GDP) militates against collective bargaining in the Public Service. The Public Service Act, Section 19 (1) states, “.... Provided that such conditions may result in an increase in expenditure chargeable on the consolidative Revenue Fund, the concurrence of the Minister responsible for Finance shall be obtained."

\section{Collective Bargaining}

The International Labor Organization (ILO) Convention, number 154, adopted in 1981, pointed out that collective Bargaining extends to all negotiations which take lace between an employer, a group of employers or one or more employers organisations on the other hand, and one or more workers' organisations on the other, for determining working conditions and terms of employment; regulating relations between employers or that organisations and a workers' organisation or worker organisations. Salamon (1998:305) defines collective bargaining as, “.... A method of determining terms and conditions of employment and regulating the employment relationship which utilizes the process of negotiation between representatives of management and employees, intended to result in agreement which may be applied across a group of employees." The study sought to find out how much collective bargaining, if any, went on in order to improve teachers salaries.

\section{Industrial Action By Teachers}

Kahn - Freud, a prominent lawyer, quoted in Davies and Freedland (1983) says "There can be no equilibrium in industrial relations without the freedom to strike. In protecting that freedom, he law protects the legitimate expectations of workers that they can make use of their collective power." The law of strikes in Zimbabwe is far from being clear. There is no clear -cut constitutional right to strike. The number of restrictions on the right to strike make it almost impossible to have a strike. Some teachers were accused of supporting the major political opposition party (Movement for Democratic Change - MDC), when they went on strike. This is because the right to strike excludes civil servants (Ref: Case of Zimbabwe Teachers' Association versus The Minister of Labour, 1996). The High Court held that the purported dismissal of teachers who had refused to return to work was unlawful. 
According to Madhuku, in his article "The right to strike", Zimbabweans strike law breaches international labour standards both as regards government and non-governmental employees. The 1996 civil service strike almost paralyzed the entire ramifications. One such outcome was the desire on the part of Government to engage staff associations such as Zimbabwe Teachers' Association (ZIMTA), Zimbabwe Nurses Association Public Service Association in discussions of salaries and conditions of service. The element of fear was established, among teachers who cited "Vana Rovai" - The Zimbabwe Republic Police (Support Unit) wing that deals with illegal gatherings

\section{Research Design And Methodology}

This study utilized the invention research design evaluate the impact of social based teacher incentives or teacher - unions and access $t$ quality education for different socio-economic strata. It is geared towards corrective action.

Statistics were generated through the use of surveys. To a large extent the research paradigm was actually quantitative, in order to determine "how much is happening, to how many, the pass rates etc). This is accordance with Mayoux (2005). In order not to miss or ignore contextual detail, I became immersed in the subject matter.

Guba (1981:45) says, descriptive research is concerned with conditions on relationships that exist, practices that prevail, beliefs,or attitudes that are held .... Effects that are being felt.... Its major purpose is to tell what is." Similarly this study focused on relationships between teachers and their employees; teachers and the parents / community; practices of school based incentives and its effects on unionism.

Cohen and Manion (1995) posit that a survey obtains information that can be analyzed, patterns obtained and comparisons made. Some light was then thrown on the pass rate schools under responsible Authorities like church organist ions and these governments, day schools in both urban and rural areas. Even the performance of run by local government (City Council and Rural District Council) was compared to that of he other school types. Borg and Gall (199) stress that surveys gather data which describe the nature and extent of specified information. Agreement with this, the study gathered data to describe the impact of school based incentives on socio-economic equalities and on the role and function of teacher organisations.

\section{Sample}

The sample was drawn from selected, school, school Development Associations/ Committees Techers' Trade Unions, Education officers and parent/ guardians. Both random sampling and purposive sampling were used. My sample had a total of 100 (one hundred) participants, as detailed below.

\begin{tabular}{|l|l|l|l|l|l|l|}
\hline Category & $\begin{array}{l}\text { Responsible } \\
\text { Authority }\end{array}$ & $\begin{array}{l}\text { No. of } \\
\text { school } \\
\text { selected }\end{array}$ & $\begin{array}{l}\text { Teachers \& } \\
\text { School heads }\end{array}$ & $\begin{array}{l}\text { SDA } \\
\text { SDC } \\
\text { officials } \\
\text { Other }\end{array}$ & Other & Total \\
\hline $\begin{array}{l}\text { Rural Boarding } \\
\text { School (Sec) }\end{array}$ & Church & 2 & 4 & 1 & - & 7 \\
\hline $\begin{array}{l}\text { Rural Day Sec } \\
\text { School R.D.C }\end{array}$ & 3 & 5 & 2 & - & 11 \\
\hline $\begin{array}{l}\text { Rural Boarding } \\
\text { Primary School }\end{array}$ & Church & 1 & 3 & 1 & - & 5 \\
\hline $\begin{array}{l}\text { Urban Boarding } \\
\text { Sec School }\end{array}$ & $\begin{array}{l}\text { Board of } \\
\text { Trustees }\end{array}$ & 2 & 4 & 1 & - & 7 \\
\hline $\begin{array}{l}\text { Urban day Sec } \\
\text { School Government }\end{array}$ & 5 & 1 & 3 & - & 3 \\
\hline $\begin{array}{l}\text { Urban Day Primary } \\
\text { School City Council }\end{array}$ & 2 & 4 & 1 & - & 7 \\
\hline ZIMTA & - & - & - & - & 5 & 5 \\
\hline P.T.U.Z & - & - & - & - & 2 & 2 \\
\hline Education Officers & - & - & - & - & 4 & 4 \\
\hline $\begin{array}{l}\text { parents / Guardians } \\
\text { Urban \& Rural }\end{array}$ & - & - & - & - & 24 & 24 \\
\hline & 16 & 39 & 10 & 35 & 100 \\
\hline
\end{tabular}

\section{Data Collection}


The pilot survey which I conducted reflected that farm-workers preferred interviews to questionnaires. With the rest of the respondents, the questionnaires were used as planned. Both structured and unstructured interviews were used, depending on circumstances prevailing. According to Haralambos (1990: 736), "Persons who are unable to read and write can still answer questions in an interview, and others who are not willing to expend their energy to write answers, may be glad to talk." This study found interviews quite appropriate.

Schools were visited to chat their profiler: infrastructure, furniture, laboratories, libraries, ICT etc

\section{Data Presentation And Analysis}

The rate of return for questionnaires was $90 \%$ on average. All the Education officers / some of whom are Part - time Tutors at The Zimbabwe Open University) and school Development Association / Committee official, all returned their completed questionnaires. Female teacher -participants were more than their male counter parts. The observed by the secretary for Education, sport and Culture I the Annual report of 2007. The teaching profession has more females than males.

Members to trade Unions and the question on motivation showed that ZIMTA had the highest number. This could be because it was formed in 1942 and currently has a membership of 62000 educators" (The Teacher Voice Magazine, October 2008). Progressive Teachers Union of Zimbabwe (P.T.U.Z) is the second largest teacher organization, which was formed in 1999. Most teachers were not aware of the difference between an association and a union. This might explain why they continue to be members of ZIMTA despite the fact that no better salaries have been negotiated upon.

\section{Responses about acceptance of school based incentives to motivate of teachers}

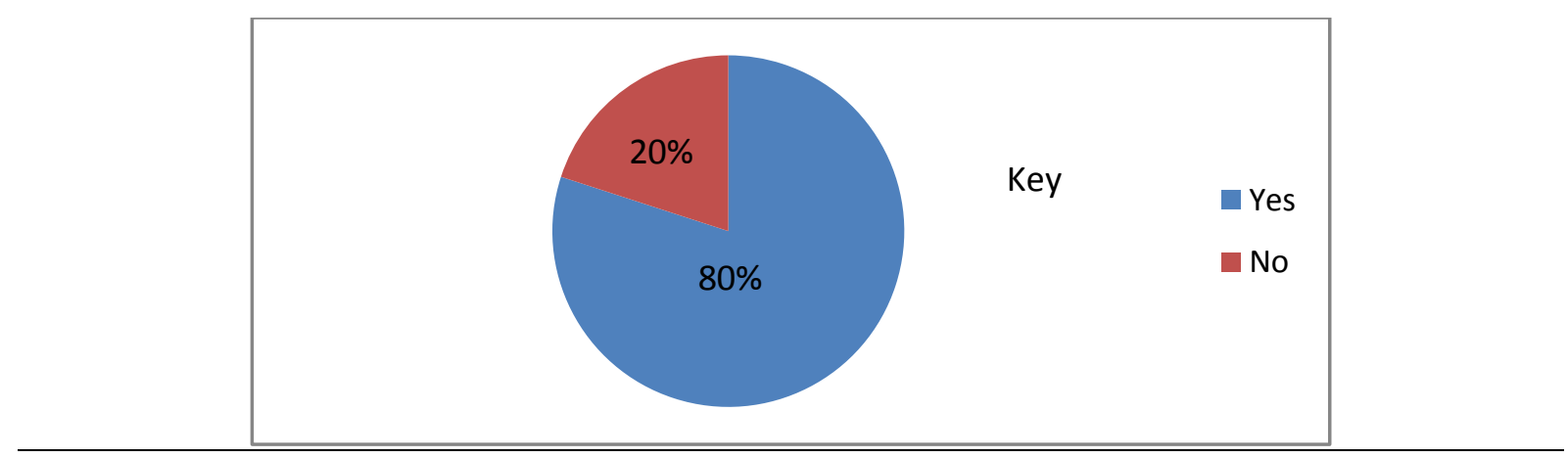

It was almost unanimously agreed that school based teacher - incentives serve to attract and retain the best teachers.

Responses On Discrimination Of Pupils Whose Parents Could Not Afford To Pay Teacher Incentives
\begin{tabular}{|l|l|l|}
\hline Response Category & Frequency & Percentage \\
\hline Yes & 54 & 75 \\
\hline No & 18 & 25 \\
\hline Total & 72 & 100 \\
\hline
\end{tabular}

So quality education was seen to be a privilege for these two could afford it, not necessarily those with excellent examination results. Before independence from the colonial era discrimination was based on racial differences. This study found that discrimination was still continuing, but currently based on socio-economic status of parents / guardians. The very poor families were being "crowded out" by the costs of education. They agreed that teacher incentives were a form of discrimination. 


\section{Did The Teacher - Incentives Destroy The Need For Teacher Associations And Unions?}

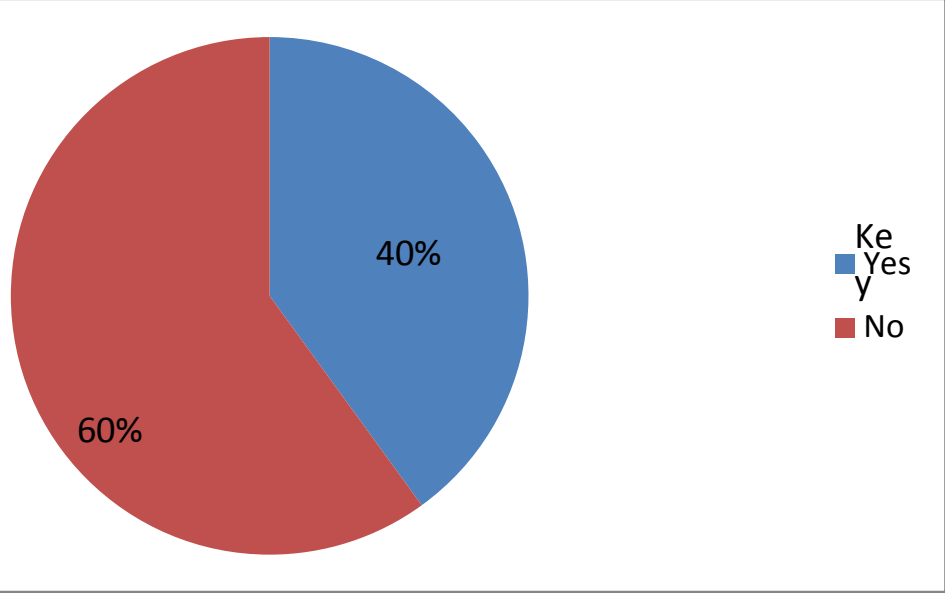

This one stimulated debate and one irate team even said, "All that ZIMTA has done is to buy those posh cars for provincial and National Executives. These cars were bought to silence our leaders. We want better salaries, that's all!" The majority felt that teacher organisations were ineffective. Some even declared that they would no join any industrial action initiated by teacher organisations because they were well paid, in the form of school based incentives.

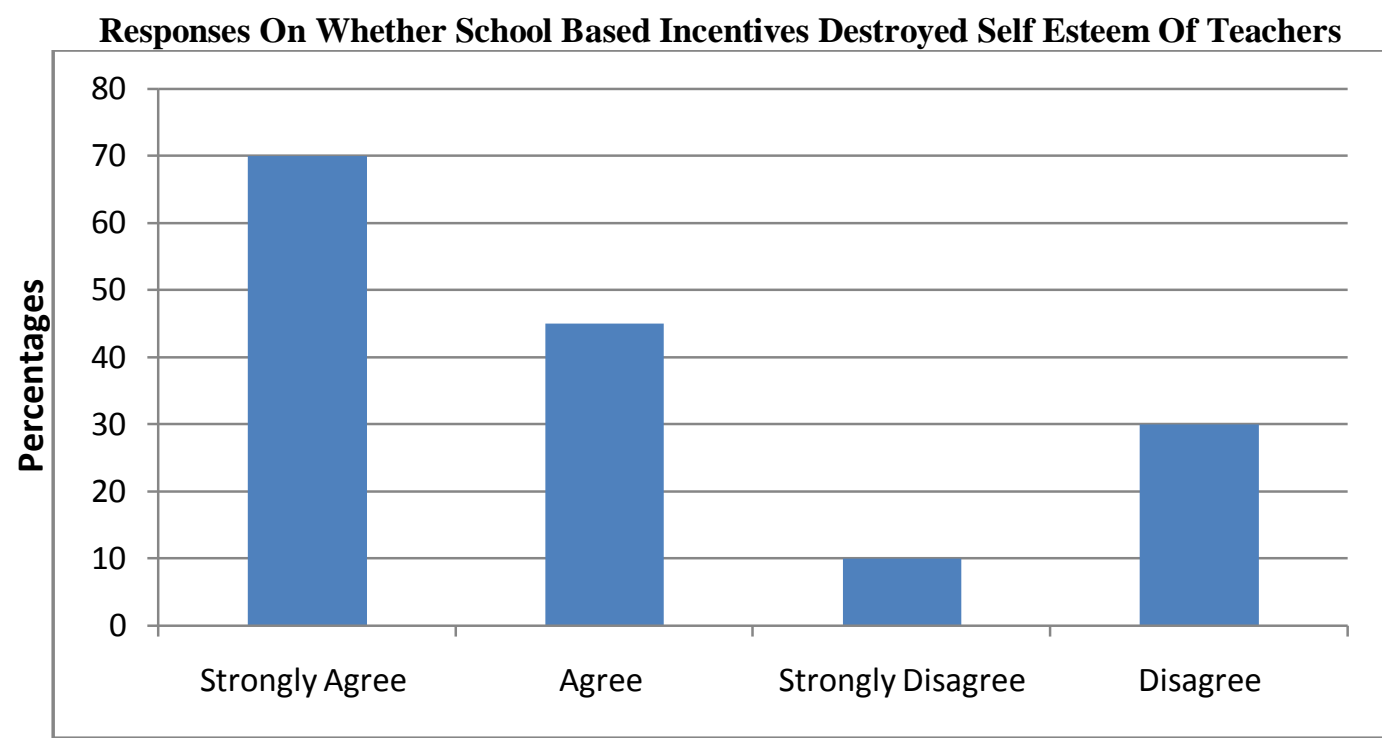

The image is the teacher, as perceived by learners and the parents / guardians, is reduced to the nadir. They are almost like beggars whose loyalty to parents (not to the employer) must be very strong. A profession that even the President of Zimbabwe ( Robert Gabriel Mugabe) joined; a profession that was known as "the mother of all professions", now forces teachers to live on hand outs from parents. Even if many parents are aware that payment of teachers' salaries should be left to government, they know that government would not pay. Through some cost-benefit analysis, they shape their children's future. Disgruntled teachers like any other category worker, do not achieve organizational goals.

Teacher incentives have a great extent over -shadowed teacher-organizations. The school based incentives will continue until the public Service Commission pays better salaries. Teacher organizations' hands were tied by the legislation and so not much can be expected until the "knotty" issues are addressed. Answers from participants showed that the onus was on the parents / guardians, to motivate their teachers. Poor families lamented that they faced problems including infrastructural inadequacies, lack of trained and motivated teachers. Their children produced poor results and so there was not much upward mobility in the socio- economic strata.

Teachers, parents, teacher organization representatives argued that they (parents) were not legally obliged to pay teacher - incentives. This confirmed the findings of the study conducted by the National Education Advisory Board (Zimbabwe; 2009: 59), which focused on low income parents in rural and urban high density centres...." However, not many were familiar with the relevant statutory Instruments.

\section{Recommendations}


- The government of Zimbabwe immediately addresses the remuneration concerns of teachers and simultaneously abolish teacher - incentives from parents.

- The same Government repeals the policy that encourages / allowed the payment of incentives. It will enable Trade Unions of incentives Association to fulfill their roles and functions

- Political overtones should not interfere with purely economic, labour relations.

- Communities use their political muscle (in the form of votes) to lobby against the school based teacher incentives.

- Government enacts policies that promote collective bargaining so as to restore equality and equity in teachers' salaries.

Further research needs to be carried out to establish the latest developments (especially in the 2013 Constitution) and assess how the predicament of the teaching profession is going to be addressed.

Ministry officials should ensure that quality is not pursued at the expense of quality in the education system.

\section{References}

[1]. Borg, WR and Gall, M.D (1996) education research an introduction. Longman, New York

[2]. Cohen, 1 and Manion, L (1995) Research Methods in Education, Cearedon Press, London Cole, G.A (1997) $4^{\text {th }}$ E.D. Personnel Management Theory and Practice, Continuum London.

[3]. Davies, P and Freedland (1983) Kahn- Freunds's Labour and The Law, $3^{\text {rd }}$ Edition Glewwe, S Newman, B and Kremmer, N (2008). The role of the teacher incentives. Allyn and Bacon New York Guba, E.G (1981) The alternative paradigm Dialogue, Sage Publishers, Newbury.

[4]. Haralambos, M (1990). Sociological themes and perspectives. MacMillan, London ILO Convection 154 (1981) Collective Bargaining Geneva, ILO Publications.

[5]. Labour Act: Chapter 28:01(2003) Harare Government Publishers Madhuku L (1997) The right to strike in Southern Africa. Volume , international Labour Review. 509.

[6]. Magaramobe M. Et.al (2003) Human Resource management ISBN 1- 77938-245-6. Zimbabwe Open University, Celoys Print, Harare

[7]. Milkovich, GT and Newman, JM (1986) Compensation Irwin, Washington Moorhead, G and Ricky W.G (1995) Managing People and Organisations. Houghton Miffin, Bonston.

[8]. National Education Advisory Board Report (2009) Harare, Zimbabwe.

[9]. Nziramasanga (1999) Zimbabwe Report of the Presidential Commission of enquiry into education and training : Zimbabwe Government Printer, Harare Salamon, M (1998) Industrial Relations- Theory and Practice, New Jersey, Prentice Hall.

[10]. Statt, D.A (1994) Psychology and the World of Work, MacMillan Press (LTD) London Vroom, VH and Deci, E.L (1970) management and Motivation: Selected Readings, Penguin Books USA 